Volume $3 \cdot$ Nomor $3 \cdot$ Juni 2020

Pege $(H a): 30-36$

(C) Universitas Pamulang

JL.Surya Kencana No.1 Pamulang, Tangerang Selatan - Banten

Telp. (021) 7412566, Fax (021) 7412491

website. :

Email : jurnalmarketing.unpam@gmail.com

\title{
Pengaruh Kualitas Pelayanan, Harga, Dan Promosi Terhadap Keputusan Pelanggan Dalam Memilih Klub Basket Satria Indonesia Tangerang Selatan
}

\author{
Dede Solihin ${ }^{1}$, Estiko Wibawanto ${ }^{2}$ \\ Universitas Pamulang, Email : dosen02447@unpam.ac.id
}

\begin{abstract}
Abstrak. Tujuan penelitiian adalah untuk mengetahui pengaruh secara parsial dan simultan kualitas pelayanan, harga dan promosi terhadap keputusan pelanggan dalam memilih klub basket satria Indonesia Tangerang Selatan. Metode asosiatif digunakan dalam penelitian ini. 150 responden adalah sampel dalam penelitian ini. Kuesioner digunakan sebagai alat pengumpulan data, dan Teknik analisis data menggunakan regresi linier berganda. Hasil penelitian menunjukan kualitas pelayanan terbukti berpengaruh positif dan signifikan terhadap keputusan pelanggan. Harga terbukti berpengaruh negatif dan signifikan terhadap keputusan pelanggan. Promosi terbukti berpengaruh positif dan signifikan terhadap keputusan pelanggan. Secara simultan terdapat pengaruh yang positif dan signifikan kualitas pelayanan, harga dan promosi terhadap keputusan pelanggan dengan nilai F hitung $70,448>F_{\text {tabel }} 2,67$.
\end{abstract}

Kata Kunci: Kualitas Pelayanan, Harga, Promosi Dan Keputusan Pelanggan.

\begin{abstract}
The research objective is to determine the partial and simultaneous influence of service quality, price and promotion on customer decisions in choosing Satria Indonesia South Tangerang basketball club. The associative method was used in this study. 150 respondents were sampled in this study. The questionnaire was used as a data collection tool, and data analysis techniques used multiple linear regression. The results showed that service quality was proven to have a positive and significant effect on customer decisions. Price is proven to have a negative and significant effect on customer decisions. Promotion is proven to have a positive and significant effect on customer decisions. Simultaneously there is a positive and significant influence on service quality, price and promotion of customer decisions with a value of Fcount 70.448> Ftable 2.6.
\end{abstract}

Keywords: Quality of Service, Prices, Promotions and Customer Decisions.

\section{A. PENDAHULUAN}

Bola basket merupakan salah satu olahraga yang masih belum mampu menyaingi ketenaran sepak bola di Indonesia. Hal tersebut tentu saja menjadi tantangan yang begitu besar bagi pelaku usaha yang ingin mendidirkan klub basket dengan tujuan profit. Daya saing yang tinggi antar penyedia jasa sekolah basket membuat setiap klub memiliki cara tersendiri untuk memenangkan persaingan tersebut. Seperti halnya yang dilakukan oleh Klub Basket Satria Indonesia yang merupakan klub basket ternama yang berada di kawasan Tangerang Selatan yang dengan selalu memberikan kualitas pelayanan yang terbaik bagi siswanya. Namun dalam perjalanan usahanya Klub Basket Satria Indonesia Tangerang Selatan mengalami permasalahan pada jumlah target siswa yang menurun. 
ISSN NO. (PRINT) 2598-0823, (ONLINE) 2598-2893

Tabel 1 Jumlah Siswa Klub Basket Satria Indonesia Tangerang Selatan

\begin{tabular}{|c|c|c|c|}
\hline Tahun & Target & Jumlah Siswa & $\%$ \\
\hline 2013 & 150 & 142 & $95 \%$ \\
\hline 2014 & 160 & 152 & $95 \%$ \\
\hline 2015 & 170 & 167 & $98 \%$ \\
\hline 2016 & 180 & 159 & $88 \%$ \\
\hline 2017 & 190 & 150 & $79 \%$ \\
\hline
\end{tabular}

Sumber: Klub Basket Satria Indonesia Tangerang Selatan

Berdasarkan tabel tersebut dapat diketahui bahwa target penerimaan siswa masih belum dapat terealisasi dengan baik, pada tahun 2013 jumlah target siwa sebesar 150 hanya mampu direalisasikan sebesar 95\%. Pada tahun 2014 jumlah target siwa sebesar 160 hanya mampu direalisasikan sebesar 95\%. Pada tahun 2015 jumlah target siwa sebesar 170 hanya mampu direalisasikan sebesar 98\%. Pada tahun 2016 jumlah target siwa sebesar 180 hanya mampu direalisasikan sebesar 88\%. Pada tahun 2017 jumlah target siwa sebesar 190 hanya mampu direalisasikan sebesar $79 \%$, selain itu selama periode tahun 2016 - 2017 jumlah siswa mengalami penurunan.

Tabel 2 Data Pelatih Berlisensi di Klub Basket Satria Indonesia

\begin{tabular}{|c|l|c|}
\hline No & \multicolumn{1}{|c|}{ Nama Pelatih } & Lisensi \\
\hline 1 & Estiko Wibawanto & B \\
\hline 2 & Ifan Sukanta & B \\
\hline 3 & Imam Satria & C \\
\hline 4 & Risky Rahmanu & C \\
\hline 5 & Kharis Agung Indarii & Belum berlisensi \\
\hline
\end{tabular}

Sumber: Data diolah

Pada tabel 2 diatas dapat diketahui bahwa dari lima pelatih yang ada di Klub Basket Satria Indonesia hanya dua pelatih saja yang sudah mendapatkan lisensi B. Dimana lisensi pelatih menunjukan kemampuan pelatih dalam mengembangkan bakat anak didiknya, dimana lisensi $\mathrm{C}$ hanya bisa melatih dengan program dasar dalam permainan basket, sedangkan lisensi B memiliki program latihan yang lebih professional.

Tabel 3 Perbandingan Harga SPP Klub Basket Satria Indonesia Tangerang Selatan Dengan Kompetitor 2017

\begin{tabular}{|c|c|c|c|}
\hline No & Klub Basket & Keterangan & Harga \\
\hline 1 & Satria Indonesia & SPP per bulan & Rp. 350.000 \\
\hline 2 & Sparkel & SPP per bulan & Rp. 150.000 \\
\hline 3 & MBC & SPP per bulan & Rp. 150.000 \\
\hline 4 & THP & SPP per bulan & Rp. 120.000 \\
\hline
\end{tabular}

Sumber: Data diolah

Berdasarkan tabel tersebut telihat jelas bahwa harga yang ditawarkan Klub Basket Satria Indonesia bila dibandingkan dengan Klub Basket sejenis masih terbilang mahal dan 
belumlah terjangkau oleh masyarakat, untuk itu pihak klub perlu mengkaji lagi penetapan harga yang sesuai dengan keadaan masyarakat sekitar guna meningkatkan jumlah siswanya.

Tabel 4 Rendahnya Kegiatan Promosi Pada Klub Basket Satria Indonesia Tangerang Selatan

\begin{tabular}{|c|l|l|}
\hline No & \multicolumn{1}{|c|}{ Indikator } & \multicolumn{1}{c|}{ Permasalahan } \\
\hline 1 & Periklanan & $\begin{array}{l}\text { 1. Minimnya penginformasian lewat surat kabar } \\
\text { baik cetak maupun elektronik } \\
\text { 2. Kurangnya ketersediaan brosur }\end{array}$ \\
\hline 2 & Promosi penjualan & Tidak adanya pemberian potongan harga \\
\hline 3 & Penjualan pribadi & $\begin{array}{l}\text { Kurangnya para staff untuk mempromosikan } \\
\text { secara langsung dengan warga sekitar (dor to } \\
\text { dor) }\end{array}$ \\
\hline
\end{tabular}

\section{Sumber: Data diolah}

Dari tabel tersebut terlihat bahwa kegiatan promosi yang dilakukan masih sangat rendah banyak indikator-indikator promosi yang masih belum dijalankan sepenuhnya oleh pengelola klub basket Satria Indonesia. Hal ini jika tidak dilakukan peningkatan kegiatan promosi akan membuat banyak calon siswa yang tidak mengetahui keberadaan klub basket Satria Indonesia.

\section{B. KAJIAN LITERATUR}

\section{Kualitas Pelayanan}

Kotler dan Armstrong (2012:49) menyatakan bahwa kualitas layanan adalah karakteristik umum dan bersifat dari prodakk atau layanan yang memengaruhi kemampuannya untuk memenuhi kebutuhan eksplisit atau implisit. Menurut Tjiptono (2014:87), "kualitas layanan adalah upaya untuk memenuhi kebutuhan dan keinginan konsumen dan keakuratan pengiriman mereka, menyeimbangkan keinginan konsumen".

\section{Harga}

Menurut Swasta (2010:30), Harga merupakan jumlah uang (jika mungkin, menambahkan beberapa item) yang diperlukan untuk mendapatkan kombinasi barang dan layanan mereka. Sementara itu, menurut Kotler dan Armstrong (2012:430), "harga adalah jumlah nilai yang ditukar konsumen dengan jumlah manfaat ketika memiliki atau menggunakan barang atau jasa produk".

\section{Promosi}

Menurut Tjiptono (2014: 219), "Promosi pada dasarnya adalah komunikasi pemasaran, yang berarti kegiatan pemasaran yang bertujuan untuk menyebarluaskan informasi, mempengaruhi atau membujuk dan / atau mengingatkan perusahaan dan produk sasaran sehingga mereka mau menerima, membeli, dan loyal kepada perusahaan. ditawarkan oleh perusahaan".

\section{Keputusan Pembelian}

Menurut Assauri (2012:141), keputusn pembeliann adalah proses pengambilan keputusan pembeliann yang melibatkan menentukan apa yang akan atau tidak akan dibeli, dan keputusn itu berasal dari tindakan masa lalu yang didapat dari pelanggan itu sendiri. 


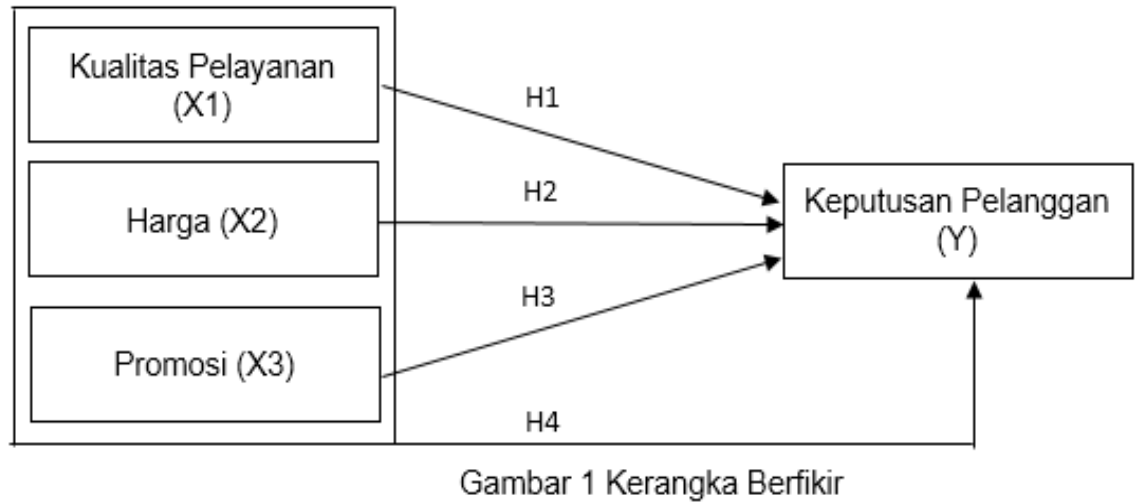

\section{METODOLOGI PENELITIAN}

Metode penelitian yang digunakann dengan metodee Asosiatiff, menurut Sugiyono (2015:44) "penelitian Asosiatif bertujuan untuk mengetahui pengaruh atau hubungan antara dua variabel lebih". Populasi disini ada seluruh siswa klub basket Satria Indonesia sebanyak 150 siswa. Dalam penelitiian, teknikk samplingg yang digunakn adalah nonprobability sampling dengan teknikk yang diambil yaitu sampling jenuh (sensus). (Sugiyono, 2015). Analisiss data menggunakan Analisis Regresi Linier Berganda.

\section{HASIL DAN PEMBAHASAN}

\section{Regresi Linier Berganda}

Tabel 5 Regresi Linier Berganda

\begin{tabular}{|c|c|c|c|c|c|c|}
\hline \multirow{2}{*}{\multicolumn{2}{|c|}{ Model }} & \multicolumn{2}{|c|}{$\begin{array}{l}\text { Unstandardized } \\
\text { Coefficients }\end{array}$} & \multirow{2}{*}{$\begin{array}{c}\text { Standardized } \\
\text { Coefficients } \\
\text { Beta }\end{array}$} & \multirow{2}{*}{$t$} & \multirow{2}{*}{ Sig. } \\
\hline & & $B$ & $\begin{array}{l}\text { Std. } \\
\text { Error }\end{array}$ & & & \\
\hline \multirow[t]{4}{*}{1} & (Constant) & 24,960 & 2,797 & & 8,924 & 0,000 \\
\hline & Kualitas Pelayanan & 0,354 & 0,050 & 0,473 & 7,058 & 0,000 \\
\hline & Harga & $-0,208$ & 0,043 & $-0,274$ & $-4,793$ & 0,000 \\
\hline & Promosi & 0,212 & 0,060 & 0,225 & 3,535 & 0,001 \\
\hline
\end{tabular}

a. Dependent Variable: Keputusan pelanggan

Sumber: Data diolah

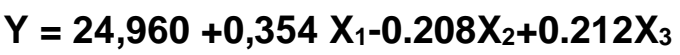

1. Nilai contant sebesar 24,960 artinya apabila kualitas pelayanann, hargaa dan promosii tidak mengalami peningkatan sama sekali, maka keputusan pelanggan akan tetap bernilai 24,960.

2. Kualitas pelayanan memperoleh nilai regresi $0,354 \mathrm{X}_{1}$ yang berarti bahwa pengaruh yang searah yang artinya jika tingkat kualitas pelayanan semakin baik dimata pelanggan maka akan membuat peningkatan keputusan pelanggan sebesar 0,354.

3. Harga memperoleh nilai regresi $-0,208 X_{2}$ yang berarti bahwa pengaruh yang tidak searah yang artinya jika tingkat harga yang ditawarkan kepada pelanggan sangat tinggi maka akan membuat penurunan keputusan pelanggan sebesar -0,208.

4. Promosi memperoleh nilai regresi $0,212 X_{3}$ yang berarti bahwa pengaruh yang searah yang artinya jika tingkat promosi yang ditawarkan kepada pelanggan semakin menarik 
ISSN NO. (PRINT) 2598-0823, (ONLINE) 2598-2893

dan insensitasnya tinggi maka akan semakin membuat peningkatan keputusan pelanggan sebesar 0,212 .

\section{Koefisien Determinasi}

Tabel 6 Koefisien Determinasi

\begin{tabular}{|l|c|r|r|c|}
\hline Model & R & R Square & Adjusted R Square & $\begin{array}{c}\text { Std. Error of the } \\
\text { Estimate }\end{array}$ \\
\hline 1 &, $769^{\mathrm{a}}$ & 0,592 & 0,583 & 5,95991 \\
\hline
\end{tabular}

a. Predictors: (Constant), Promosi, Harga, Kualitas Pelayanan

b. Dependent Variable: Keputusan pelanggan

Sumber: Data diolah

Dari Tabel 6, diperoleh bahwa nilai Rsquare dari 0,592 berarti bahwa 59,2\% dari variabel keputusan pelanggan dipengaruhi dari variabel kualitass pelayanann, hargaa dan prmosi, sedangkan sisanya $40,8 \%$ dijelaskan oleh faktor-faktor lain yang tidak termasuk dalam model.

\section{Uji t Parsial}

Tabel 7 Uji t Parsial

\begin{tabular}{|c|c|c|c|c|c|c|}
\hline \multirow{2}{*}{\multicolumn{2}{|c|}{ Model }} & \multicolumn{2}{|c|}{$\begin{array}{l}\text { Unstandardized } \\
\text { Coefficients }\end{array}$} & \multirow{2}{*}{$\begin{array}{c}\begin{array}{c}\text { Standardized } \\
\text { Coefficients }\end{array} \\
\text { Beta } \\
\end{array}$} & \multirow{2}{*}{$\mathrm{t}$} & \multirow{2}{*}{ Sig. } \\
\hline & & B & $\begin{array}{l}\text { Std. } \\
\text { Error }\end{array}$ & & & \\
\hline \multirow[t]{4}{*}{1} & (Constant) & 24.960 & 2.797 & & 8.924 & 0,000 \\
\hline & Kualitas Pelayanan & 0,354 & 0,050 & 0,473 & 7,058 & 0,000 \\
\hline & Harga & $-0,208$ & 0,043 & $-0,274$ & $-4,793$ & 0,000 \\
\hline & Promosi & 0,212 & 0,060 & 0,225 & 3,535 & 0,001 \\
\hline
\end{tabular}

a. Dependent Variable: Keputusan pelanggan

Sumber: Data diolah

1. Berdasarkan hasil pengujian statistik pada tabel 7 angka dari thitungg $7,058>t_{\text {tabell }} 1,976$ dengan angka sig $(0,000<0,05)$ menunjukan diterimanya $\mathrm{H} 1$ dan ditolaknya $\mathrm{Ho} 1$ yang berarti bahwa kualitass pelayanan memiliki pengaruh positf dan signifikn terhadap keputusan pelanggan.

2. Berdasarkan hasil pengujian statistik pada tabel 7 angka dari $t_{\text {hitungg }}-4793>t_{\text {tabell }}-1,976$ dengan angka sig $(0,000>0,05)$ menunjukan diterimanya $\mathrm{H} 2$ dan ditolaknya $\mathrm{Ho} 2$ yang berarti bahwa harga memiliki pengaruh negatif dan signifikn terhadap keputusan pelanggan.

3. Berdasarkan hasil pengujian statistik pada tabel 7 angka dari $t_{\text {hitungg }} 3,535>t_{\text {tabell }} 1,976$ dengan angka sig $(0,001>0,05)$ menunjukan diterimanya $\mathrm{H} 3$ dan ditolaknya Ho3 yang berarti bahwa promosi memiliki pengaruh positf dan signifikn terhadap keputusan pelanggan. 
ISSN NO. (PRINT) 2598-0823, (ONLINE) 2598-2893

\section{Uji F Simultan}

\begin{tabular}{|c|c|c|c|c|c|}
\hline Model & $\begin{array}{c}\text { Sum of } \\
\text { Squares }\end{array}$ & $\mathrm{df}$ & $\begin{array}{c}\text { Mean } \\
\text { Square }\end{array}$ & $\mathrm{F}$ & Sig. \\
\hline \begin{tabular}{l|l}
1 & Regression
\end{tabular} & 7511,341 & 3 & 2503,780 & 70,488 & $000^{b}$ \\
\hline \begin{tabular}{|l|} 
Residual \\
\end{tabular} & 5185,992 & 146 & 35,520 & & \\
\hline Total & 12697,333 & 149 & & & \\
\hline
\end{tabular}

Hasil di atas menunjukkan bahwa angkaa signifikansii lebih kecil dan lebih rendah dari 0,05 atau $(0,000<0,05)$, serta $F_{\text {hitungg }} 70,488>F_{\text {tabell }} 2,67$ membuat pilihan variabel kualitas pelayanan, harga dan promosi adalah tepat dan cocok untuk menjelaskan variabel keputusan pelanggann dengan pengaruh positif dan signifikan.

\section{E. KESIMPULAN}

1. Hasil pengujian hipotesis $(\mathrm{H} 1)$ membuktikan bahwa semakin baik tingkat kualitas pelayanan yang diberikan oleh pihak pengelola klub basket maka akan semakin tinggi tingkat keputusan pelanggan dalam memilih Klub Basket Satria Indonesia Tangerang Selatan dan pengaruhnya bersifat positiff dan signifikann.

2. Hasil pengujian hipotesis $(\mathrm{H} 2)$ membuktikan semakin tinggi dan mahal tingkat harga yang ditwarkan kepada pelanggan maka akan semakin rendah juga keputusan pelanggan Dalam Memilih Klub Basket Satria Indonesia Tangerang Selatan dan pengaruhnya bersifat negatiff dan signifikn.

3. Hasil pengujian hipotesis (H3) membuktikan semakin baik tingkat promosi yang ditawarkan maka akan semakin tinggi juga keputusan pelanggan Dalam Memilih Klub Basket Satria Indonesia Tangerang Selatan dan pengaruhnya bersifat positiff dan signifikann.

4. Hasil pengujian hipotesis $(\mathrm{H} 4)$ membuktikan bahwa semakin baik tingkat kualitas pelayanan yang diberikan, harga yang sesuai, dan promosi yang menarik maka akan semakin tinggi juga keputusan pelanggan Dalam Memilih Klub Basket Satria Indonesia Tangerang Selatan dan pengaruhnya bersifat positiff dan signifikann.

\section{DAFTAR PUSTAKA}

Kotler, P. \& Armstrong, G. (2012). Prinsip-prinsip Pemasaran. Edisi 13. Jilid 1. Erlangga: Jakarta.

Lesmana, R. (2017). Pengaruh Citra Perusahaan Terhadap Keputusan Pembelian Konsumen Pt. Garuda Indonesia Tbk.(Persero). Jimf (Jurnal Ilmiah Manajemen Forkamma), 1(1).

Sofjan, A. (2012). Strategic Marketing Sustaining Lifetime Customer Value. Jakarta. Raja Grafindo Persada. 
Solihin, D. (2020), Faktor-Faktor Yang Mempengaruhi Kinerja Pemasaran Pada PT Prima Ufuk Semesta (Studi Empiris Pada Outlet Rekanan PT. Prima Ufuk Semesta di Wilayah JABODETABEK), Jurnal Semarak, Vol. 3. No. 1.

Sugiyono. (2015). Metode Penelitian Kuantitatif Kualitatif R\&B. Bandung: Aflabeta.

Swastha, B. (2010). Manajemen Pemasaran: Analisa dan Perilaku Konsumen. Yogyakarta. BPFE.

Tjiptono, F. (2014). Pemasaran Jasa. Andi: Yogyakarta. 